\title{
COMISSÃO DE CONTROLE DE INFECÇÃO HOSPITALAR
}

\author{
Lidvina Horr * \\ Inez Maria Oro * \\ Alacoque Lorenzini * \\ Lorena Machado e Silva*
}

\begin{tabular}{l|l|}
\cline { 2 - 2 } & RBEn/04 \\
\hline
\end{tabular}

HORR, L. e Colaboradores - Comissāo de controle de infecçāo hospitalar. Rev. Bras. Enf.; DF, 31 : 182-192, 1978.

\section{I - INTRODUÇĀO}

Historicamente, o controle das infecçōes bacterianas sistêmicas teve início em 1935, com o emprego da sulfanilamida e a seguir, com a descoberta da penicilina por Fleming.

Novas investigaçōes levaram a aumentar de muito a eficácia da quimioterapia bacteriana. Porém, um grande númer? de microrganismos adquiriu resistência a muitos agentes antimicrobianos, por um ou mais dos seguintes mecanismos: mutação, transdução, transformação e, conjugação.

Este problema de resistência bacteriana aos antibióticos é um dos mais importantes e que mais preocupa aos pesquisadores, bem como aos profissionais da área de saúde. As soluçōes para o mesmo, apóiam-se geralmente, sobre 0 desenvolvimento de novos e mais eficazes agentes antimicrobianos.
"As infecçōes hospitalares, segundo estimativas consideradas otimistas, matam mais de 50 mil pessoas por ano no Brasil". (O jornal "O Estado de São Pauio").

Segundo ZANON e colaboradores, "são conhecidas até a presente data, taxas de infecção hospitalar de apenas 4 hospitais brasileiros, que se situam entre 4,1 a $13,2 \%$, e nos Estados Unidos variam entre 3 a $15 \%$.

"Pela gravidade do problema é necessário instituir-se, no" Hospital, medidas de controle e tratamento da infecção hsopitalar, com a finalidade primordial de zelar pelo bem-estar do paciente, conseguindo a diminuição da permanência do mesmo no hospital, e conseqüentemente a diminuição do custo/paciente".

Para tais medidas visamos neste trabalho:

- promover a conscientização de pessoas, em nivel de decisāo, para a importância da constituição de co-

- Mestrandas da Universidado Federal de Santa Catanna. 
HORR, L. e Colabosadores - Comissão de controle de infecção hospitalar. Rev. Bras. EnR.; DF, 31 : 182-192, 1978.

missōes de controle de infecçāo hospitalar, órgāo normativo, que centraliza o problema permitindo o pronto reconhecimento dos surtos nas diversas áreas do hospital, bem como, determinaçāo das medidas de prevençāo e controle;

- conscientizar os administradores sobre a importância de existir ums Comissāo de Controle de Infecção Hospitalar (C.C.I.H.), considerando os graves riscos de morbidade $e$ mortalidade, bem como o custo do tratamento e média de permanência dos pacientes nas Instituiçōes de Saúde;

- oferecer subsídios para a implantação de comissōes de controle de infeç̧ōes nas Instituiçōes de Saúde.

\section{II - DESENVOLVIMENTO}

1. Fontes e causas de infecção hospitalar

A interação entre os agentes mórbidos com o meio ambiente e o homem pode determinar uma infecção a partir do mimento em que diminuem as defesas naturais do organismo em relaçāo ao agente agressor.

A infecçāo hospitalar, segundo a maioria dos autores, inclui os processos infecciosos adquiridos no hospital e os nāo identificados na admissão do paciente por dificuldade diagnóstica ou prolongado periodo de incubaçāo, e que se manifestem durante a sua permanência $e$ até mesmo depois de sua alta.

No hospital, as principais fontes de infecção decorrem de causas ligadas ao ambiente, pessoal, equipamento, material, veículos, desempenho deficiente das técnicas de trabalho e uso indiscriminado de antibióticos.

\section{Constituição de uma C.C.I.H.}

Paralelamente aos avanços tecnológicos na área da Saúde aumenta o pro- blema das infecçōes nos ambientes hospitalares, particularmente das infecçōes cruzadas, agravado pelas novas amostras de bactérias resistentes aos antibióticós.

Medidas efetivas devem ser adotadas visando a reduçāo e eliminaçāo das infeç̧ōes, proporcionando maior segurança aos pacientes, visitantes e servidores do hospital, destacando-se como medida prioritária a criaçāo de uma C.C.I.H.

\subsection{Estrutura física}

A área física destinada para o funcionamento de uma C.C.I.H. dependerá do tamanho e condiçōes de cada hospital, bem como do número e gravidade da ocorrência de infecçōes. Acredita-se que a C.C.I.H. deva dispor no mínimo de uma sala para chefia e reuniōes, secretaria e arquivo, laboratório para bacteriologia epidemiológica.

\subsection{Estrutura funcional}

2.2.1. Posiçāo da C.C.I.H. no organograma

A C.C.I.H. deve estar diretamente subordinada a Administraçāo superior, o que iavorecerá a comunicaçāo e resoluçāo imediata dos problemas referentes às infecçōes.

\subsubsection{Número e qualificaçāo do pes- soal}

A Comissão de Controle de Infecçāo Hospitalar (C.C.I.H.) é atualmente uma necessidade sintida em muitos hospitais e recomendada desde há muito pela Associaçāo Americana de Hospitais, através de seu Conselho especialmente formado para estudar as infecçōes e seu controle.

Conscientizados da problemática da infecçāo hospitalar, suas repercusšôes negativas e graves conseqüências, tais como aumento da taxa de mortalidade, morbidade, taxa elevada de ocupaçāo, 
HORR, L. e Colaboradores - Comissão de controle de infecção həspitalar. Rev. Bras. Ene; DF, $31:$ 182-192, 1978.

média de permanência, é que hospitais de pequeno, médio e grande porte criaram sua C.C.I.H. O número de componentes de uma Comissão depende de uma série de fatores, tais como: tipo de hospital, número de leitos, taxa de ocupação e taxa de infecção. Assim, em hospitais pequenos, a responsabilidade poderá ser confiada apenas a um profissional, que reúna conhecimentos de bacteriologia, epidemiologia e de enfermagem.

Em hospitais de médio e grande porte, fazem parte da comissão, vários profissionais da área da saúde a saber:

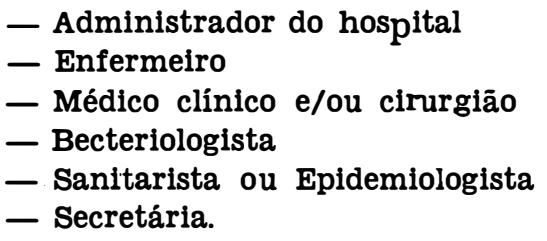

A primeira vista pode parecer onerosa a existência de uma C.C.I.H. Atualmenmente, as poucas comissōes já em funcionamento e a vasta bibliografia a respeito, provam ser um investimento para o hospital.

Não é necessário lembrar que os membros da Comissão devem ter horas disponiveis para estas atividades por se tratar de um trabalho difícil que requer muito tempo, eficiência e vigilância permanente para que possa atingir seus objetivos.

Como o Serviço de Enfermagem repre senta mais de $50 \%$ do pessoal hospitalar, é aconselhável que tenha um representante Enfermeiro, em tempo integral, para atuar como um dos membros executivos e fiscalizadores da Cimissão.

\subsubsection{Setores e competência da C.C.I.H.}

Para maior dinamismo e eficácia dos trabalhos, a Comissão pode ser estrutu- rada em vários setores com atribuiçōes definidas, a saber:

- Setor normativo: ao qual compete estudar e aprovar os recursos usados ou a serem usados para o controle e profilaxia de infecçōes.

- Setor informativo e de estatistica: compete notificar todos os casos de infecção ou sugestivos a infecção e as transgressōes das normas e rotinas da C.C.I.H., ao setor executivo e fiscalizador.

- Setor executivo e fiscalizador: ao qual compete executar, fazer executar e fiscalizar as normas estabelecidas e aprovadas pelo setor normativo.

- Setor laboratorial: ao qual compete executar testes laboratoriais, quer esclarecedores de diagnóstico ou de controle geral.

A introdução destes setores na estrutura da C.C.I.H. não significa maior número de participantes na Comissão, mas uma maior organização e divisão de responsabilidade. Os membros constituintes poderão fazer parte de vários setores.

\section{Funçōes da C.C.I.H.}

As funçōes da C.C.I.H., estão diretamente ligadas às fontes e causas da infeç̧ão.

Ao se organizar uma Comissão, esta deve evidentemente montar o seu programa, partindo de um minucioso diagnóstico situacional de seu hospital, dando prioridade às áreas chamadas críticas.

if sumamente importante a conscientização geral de todos os servidores do hospital através da Educação e Orientação nas práticas de técnicas assépticas, atingindo desde o servente de limpeza até a Administração Geral. $O$ bom êxito na profilaxia e controle das infecçōes, depende do esforço permanente e sistematizado de todo pessoal hospitalar e 
FORR, L. e Colaboradores - Comissão de controle de infecção həspitalar. Rev. Bras. Enf.; DF, $31: 182-192,1978$.

não apenas da C.C.I.H., isoladamente, pois trata-se de um trabalho difícil que exige a colaboração contínua e eficiente de todos.

As atividades de relevância da C.C.I.H. podem ser agrupadas em:

3.1. Controle do ambiente

3.2. Controle do pessoal

3.3. Controle de produtos químicos

3.4. Elaboração de normas e rotinas

3.5. Investigação epidemiológica

3.6. Reuniōes periódicas.

Estas desdobram-se em várias outras, das quais apresentaremos alguns aspectos sob forma de sugestão:

\subsection{Controle do ambiente}

As açōes da C.C.I.H. devem estar planejadas para manter o controle das infecçōes em todas as áreas do ambiente hospitalar, dando, porém, prioridade às áreas críticas. Assim os esforços da Comissão estarão voltados para:

- Elaboração, controle e atualizaçâo de normas e rotinas referentes à limpeza e desinfecção dos ambientes, estabelecendo a freqüência, tipo de desinfetante, dando ênfase especial às áreas críticas: centros cirúrgico, obstétrico, berçário, sala de recuperação pós anestésica, unidade de terapia intensiva, pediatria, isolamento, serviço de Nutrição e Dietética.

- Programas de treinamento e atualização sobre limpeza e desinfecção de ambiente.

- Controle das desinfecçōes concorrentes.

- Controle das desinfecçōes terminais.

\subsection{Controle de pessoal}

A maioria dos autores consideram o elemento humano, servidores do hospi- tal, visitantes e em particular o paciente, como sendo a maior fonte de infecção hospitalar. também sabido, no que se refere aos servidores, que, independente da escala hierárquica, aqueles que estão em contato direto com o paciente são fontes de infecção hospitalar.

A atenção da C.C.I.H. deve estar voltada para os três aspectos de pessoal e programar suas açōes no sentido de proteger esta mesma população, bem como prevenir e combater os agentes infecciosos.

Cada hospital através de sua C.C.I.H. deve estabelecer as prioridades e a freqüência dos exames que julgar necessários ao controle sanitário de seu pessoal, levando em consideração as fontes de infecção e tipos de agentes identificados e as possibilidades de recursos materiais e humanos do Serviço de Análises Clínicas.

Entre outras atividades no controle de pessoal a Comissão deverá executar:

Em relação ao paciente:

- Controle permanente de qualquer caso suspeito ou confirmado através da investigação epidemiológica.

- Educação para a Saúde dos pacientes internados e de ambulatório; supervisão e controle do comportamento esperado.

- Isolamento de todos os pacientes com suspeita ou infecção instalada.

- Supervisão e controle da realização dos exames indicados na admissão estabelecidos pela Comissão: cultura de secreção de rino e orofaringe, de lesōes cutâneas, e exame de fazes.

- Supervisão do preparo do campo operatório em pacientes cirúrgicos.

Em relação aos visitantes:

- Programas de Educação para a Saúde. 
HORR, $I_{n}$ e Colaboradores - Comissão de controle de infeç̧åo hospitalar. Rev. Bras. Enf.; DF, 31 : 182-192, 1978.

- Controle dos horários e número die visitas por paciente.

- Limitação de idade para visitantes.

- Orientação sobre a transmissão de infecçōes e infecção cruzada.

Em relação aos servidores:

- Programas permanentes de profilaxia, controle de infecçōes hospitalares.

- Programas de Educação para a Saúde.

- Treinamento de todos os servidores na prática de técnicas assépticas desde o Servente de limpeza até $o$ Administrador no sentido de proteger, prevenir e controlar as infecçōes.

- Controle dos exames periódicos estabelecidos pela comissāo no ato da admissão dos servidores.

- Controle periódico da saúde dos servidores e pesquisa bacteriológica de material de naso-faringe, pele, fezes, mãos, de acordo com a necessidade sentida.

- Elaboração, supervisão e atualização de rotinas referentes às técnicas de assepsia: degermação, desinfecção, sanificação, desinfestaçāo, higiene, limpeza, esterilizaçāo, escovação das mãos, uso de aventais. máscaras, pró-pés, manipulação de medicamentos, eliminação do material de curativos, de dejetos, $i$ secreçōes do paciente e do lixo em geral.

- transporte, separaçāo e lavagem da roupa, cobertores e colchōes. sujos e/ou contaminados;

- objetos utilizados nos cuidados higiênicos dos pacientes;

- limpeza e desinfecção de pratos, copos e talheres, de uso comum dos pacientes;

- limpeza, desinfecção e esterilização de todo o equipamento e material hospitalar, como por exemplo: máscaras, nebulizadores, cânulas de traqueotomia, bolsas de água quente e gelo, aspiradores, frascos de drenagem, respiradores artificiais, seringas, agulhas, material cirurgico, aparelhos de anestesia, catéteres e sondas;

- empacotamento de material e instrumental a ser esterilizado;

- controle periódico do funcionamento dos aparelhos de esterilização e câmaras frigorificas;

- lavagem e preparo de alimentos crus, frutas e demais gêneros alimentícios;

- destino das sobras de alimentos.

\subsection{Controle dos produtos químicos}

ZANON e colaboradores afirmam que "na maioria dos hospitais brasileiros, desinfetantes e antissépticos são escolhidos em função do preço, de avaliaçōes bacteriológicas inadequadas como exposição de placas de meio de cultura ou de preferências individuais subjetivas, pois as empresas não declaram a composiçāo quantitativa de seus produtos".

Embora se saiba que as soluçōes desinfetantes e antissépticas podem sofrer contaminação, . acarretando infecçōes graves e, até mesmo fatais, e/ou ainda apresentarem-se com atividade antimicrobiana não satisfatória ou mesmo nula, não é dada a devida atençao a esse problema.

Cabe, portanto, à C.C.I.H.:

- a Seleção dos produtos químicos germicidas, desinfetantes, antissépticos, agentes de limpeza;

- o controle da sua aquisiçāo e emprego;

- o teste bacteriológico periódico;

- a elaboraçāo de normas e rotinas quanto ao uso dos mesmos. 
HORR, L. e Colaboradores - Comissão de controle de infecçāo hospitalar. Rev. Bras. Ent.; DF, $31:$ 182-192, 1978.

\subsection{Elaboração de Normas e rotinas}

- Normas:

As normas estabelecem em principios científicos e de autoridade o que e como deve ser feita em determinada situação.

Vários aspectos importantes devem ser considerados, como:

- Normas da organização da C.C.I.H.

- Normas referentes ao Pessoal.

- Normas referentes ao orçamento.

- Normas referentes ao relacionamento interno e externo de comissāo.

- Normas técnicas relacionadas às características e classificaçāo das infecçōes.

ZANON e colaboradores em trabalho elaborado para o I Encontro Nacional de Diretores dos Hospitais Próprios do INPS e IPASE, apresentam em apêndice um resumo de normas técnicas aprovadas pelo CDC - Center for Disease Control, do Departamento de Saúde dos Estados Unidos, consagradas e aceitas internacionalmente. (Anexo)

\section{- Rotinas:}

As rotinas consistem na descrição sistematizada dos passos a serem dados para a execuçāo das açōes componentes de uma atividade. São o produto do estudo e vivência adquiridas nas rotinas diárias, no trabalho de planejamento, na orientaçāo e no treinamento do pessoal.

A C.C.I.H. é responsável pela elaboração de rotinas administrativas, relacionadas ao material, equipamento, produtos químicos e procedimentos.

\subsection{Investigaçāo epidemiológica}

A vigilância epidemiológica possibilita a tomada de decisōes corretas em tempo oportuno.

A C.C.I.H. atuará através de:

- levantamento e análise de um conjunto de indicadores:
- taxa de incidência e de prevalência de infecçōes hospitalares;

- taxa de infecção em cirurgias nāo contaminadas;

- taxa de infecção em cirurgias potencialmente contaminadas;

- taxa de letalidade por infecçōes hospitalares;

- taxa de infecçāo por microrganismo específico;

- coeficientes de sensibilidade aos antimicrobianos;

- indice de consumo de antimicrobianos;

- notificação compulsória pelos médicos, dos casos de infecção mediante preenchimento de Ficha de Notificação de Infecçōes, constante de todos os prontuários;

- identificação, pelos enfermeiros, dos prontuários de pacientes em uso de antimicrobianos, com ou sem infecçāo;

- encaminhamento, após alta, dos prontuários dos pacientes com infecção, à C.C.I.H. para estudo;

- pesquisas periódicas de prevalencia de infecção;

- levantamentos bacteriológicos da freqüência e dos coeficientes de sensibilidade de microrganismos isolados em pacientes, visitantes e funcionários;

- levantamento e controle do consumo de antimicrobianos.

Este conjunto de açōes de investigagaçāo epidemiológica dá à C.C.I.H. maior possibilidade de controle das infecçōes, e conseqüentemente de eliminar as causas.

\subsection{Reuniōes periódicas}

Periodicamente a C.C.I.H. deve reunir-se para analisar e avaliar programas, número, natureza e quantidade de 
HORR, L. e Colaboradores - Comissão de controle de infecção hospitalar. Rev. Bras. Enf.; DF, $31: 182-192,1978$.

infecçōes e programar novas açōes. Para que os objetivos da C.C.I.H., sejam atingidos, é imprescindivel a participação nestas reuniōes de representantes médicos, enfermeiros, chefes de serviço, principalamente quando novas medidias deverão ser implantadas.

4. Áreas criticas do hospital

A C.C.I.H. deve preocupar-se com todas as áreas, considerando o Hospital com uma unidade. Algumas áreas, porém, pela finalidade a que se destinam, merecem atenção especial, tais como:

- bercário;

- centro cirúrgico;

- centro obstétrico;

- centro de recuperação pós-anestésica;

- unidade de terapia intensiva;

- centro de material e esterilização;

- pediatria;

- isolamento;

- serviço de nutrição e dietética;

- lavanderia.

\section{O Administrador na C.C.I.H.}

O Administrador do hospital, responsável pela segurança dos pacientes conscientizado da gravidade do problema da infecção hospitalar, deve, não somente incentivar a criação da C.C.I.H., como também, tomar parte da mesma.

Entre as suas atividades como membro da comissão, destacam-se:

- manter um serviço de vigilância sanitária para o pessoal;

- oferecer condiçōes para identificação dos agentes etiológicos pelos Serviços de Análises Clínicas;

- estimular os serviços médicos, de enfermagem, Nutrição e Dietética, Lavanderia, Limpeza e Auxiliares de Diagnóstico e Tratamento a tomarem parte na elaboração de normas e rotinas referentes à prevenção e controle das infecçōes;
- estabelecer critérios exigentes para a indicação dos responsáveis pelos Serviços de Limpeza e Lavanderia, para através da qualificação destes, reduzir a freqüência das infecçōes;

- permitir a compra de antissépticos e desinfectantes que atendam os critérios estabelecidos pela Comissão;

- tornar compulsória, a notificação das infecções à C.C.I.H. pelos profissionais da equipe de saúde;

- dar condiçōes materiais e humanis para que a comissão possa desenvolver seus trabalhos;

- assessorar nas construçōes e reformas do Hospital para facilitar a implantação das medidas de redução de infecções.

6. A chefia de Enfermagem na C.C.I.H.

A Enfermagem representa papel importante no controle de infecçōes porque mantém maior contato com os pacientes. Assim, a Enfermagem atraves de sua chefia, poderá prestar valiosa colaboração à C.C.I.H. assumindo responsabilidades como as que seguem:

- cooperação consciente na elaboração das normas, rotinas e técnicas adotadas pela Comissão;

- orientação e supervisão do pessoal na execução das normas e rotinas elaboradas pela comissão;

- eleboração das normas e rotinas referentes às técnicas de Enfermagem;

- realização de trabalhos de investigação para certificar-se da observância das normas e rotinas;

- programação e realização de cursos de atualização no que concerne à prevenção e a controle de infecçōes;

- assessoria nas construçōes e reformas do Hospital para possibilitar a implantação das medidas de prevenção e controle das infecçōes; 
HORR, L. e Colaboradores - Comissāo de controle de infecçāo hospitalar. Rev. Bras. Enf.; DF, 31 : 182-192, 1978.

- ampliação dos conhecimentos sobre antissépticos e desinfetantes;

- conscientização dos pacientes, visitantes e servidores sobre os perigos das infecçōes hospitalares e a importância de sua participação na prevenção das mesmas.

\section{III - CONCLUSOES}

Acreditamos que:

- o problema das infecçōes hospitalares se reveste, na nossa realidade, de uma importância transcendental;

- as Instituições de Saúde, desde que adequadamente concientizadas, usufruirão de vantagens sócio- econômicas e políticas na implantaçāo de uma C.C.I.H.;

- a existência de uma C.C.I.H. proporciona a elevação da qualidade da assistência aos pacientes nos níveis de promoção, proteção, recuperação e reabilitação);

- economicamente, a existência de uma C.C.I.H. elevará a produtividade em função da diminuição da média de permanência e da maior rotatividade e ocupação dos leitos;

- independente do número de leitos e de profissionais lotados em cada Instituição de Saúde, é viável a implantação e funcionamento de uma C.C.I.H., desde que sejam feitas adaptaçōes de acordo com a realidade;

- as condições para o ensino, na área da saúde serão diretamente proporcionais ao nível de atuação da C.C.I.H.

\section{IV - RECOMENDAÇŐES}

1. Considerando as vantagens que oferece a redução das infecçōes hospitalares, entre outras diminuição do risco de mortalidade e morbidade, do custo do tratamento e da média de perma- nência dos pacientes o que resulta na maior rotatividade dos leitos, recomenda-se:

1.1. Aos órgãos deliberativos das Instituiçōes de Saúde que:

- Criem Comissōes de Controle de Infecção Hospitalar, a curto e médio prazo levando em consideração os problemas específicos de infecção de cada Unidade Hospitalar;

- Promovam cursos para Administradores, sobre infecção hospitalar, conscientizando-os do problema;

- Forneçam os subsídios necessários a manutenção do funcionamento das C.C.I.H. em nível adequado.

1.2. Aos administradores dos Hospitais que:

- mantenham-se atualizados sobre o problema das infecçōes hospitalares;

- participem das C.C.I.H. dos seus hospitais;

- apoiem e estimulem os membros da comissão;

- liberem elementos participantes da Comissão, para suas atividades, de acordo com o volume de seus trabalhos;

- Providenciem recursos materiais e financeiros para garantir o funcionamento da Comissão;

- colaborem na educação e orientação formal e informal, permanente e obrigatória, de todos os servidores do hospital através de programas de atualização e/ou de treinamento.

2. Considerando a importância da existência de normas e rotinas que determinem a atuação do pessoal de Enfermagem na execução de procedimentos técnicos; a necessidade da orientação e supervisão na execução das mesmas, recomenda-se:

Aos chefes de Serviços de Enfermagem que: 
HORR, L. e Colaboradores - Comissāo de controle de infecção hospitalar. Rev. Bras. Enf.; DF, 31 : 182-192, 1978.

- tomem parte ativa na Comissão designando um enfermeiro em horário integral;

- colaborem na elaboração de normas e rotinas especificas de Enfermagem;

- supervisionem e orientem a execução fiel das mesmas;

- Colaborem na atualização e treinamento do pessoal de Enfermagem.

3. Considerando que os servidores da Instituição de Saúde constituem a massa crítica diretamente responsável pela execução de atividades visando diminuir os riscos de infecção hospitalar, recomenda-se:

A todos os servidores do Hospital que:

- mantenham-se atualizados sobre o problema das infecçōes hospitalares;

\section{REFERENCIAS}

1. AQUIAR, N., ZANON, U., MELLO, C.G., ALONSO, L.M., COSTA, B.G., BLEY, J.L. A repercussão do controle cie antimicrobianos em alguns indicadores hospitalares. Vida hospitalar. 10(2): 116-120, 1976.

2. CORDOVA, C.M. A comissão de controle de infecção. Enfoque. 1(4):5-5, junho, 1973.

3. GOODMAN, L.S. e GILMAN, A. As Bases Farmacológicas da Terapêutica. Rio de Janeiro, Buanabara Kogan, 1973. $1615 \mathrm{p}$.

4. GOTH, A. Farmacologia Médica. Rio de Janeiro, Guanabara Koogan, 1975. $694 \mathrm{p}$.

6. HENDRIKXX, H. M. Manual do Serviço de Enfermagem da Sociedade Beficiente São Camilo. Sāo Paulo. Grafikor, 1975. 218 p.

6. MARQUES, M.M., ARAGAO, L. G. A infeç̧ão no hospital. Revista Paulista de Hospitais. 22(12) : 54\$-546, dez. 1974.

7. MODERNAS TECNICAS DE ASSEPSIA HOSPITALAR. Jornal Brasileiro de Medicina. Guanabara, $\mathrm{Pu}$ blicaçōes Cientificas. s.n.t. p. 1-9.

8. SELDMAN, M.A. Administração do Serviço de Enfermagem. São Paulo. Grafikor, 1975. $205 \mathrm{p}$.
- participem dos cursos de atualização e/ou treinamento oferecidos;

- cumpram rigorosamente as normas estabelecidas pela comissão;

- sigam rigorosamente as rotinas estabelecidas pela comissão.

4. Considerando que as Instituiçōes de saúde se caracterizam como "campo" de elevada importância na formação de futuros profissionais da área da saúde e que a presença de acadêmicos deverá contribuir para manutenção no controle das infecçōes hospitalares recomenda-se:

As Instituiçōes de Ensino que:

- instruam seus professores e alunos acerca das normas e rotinas estabelecidas pela comissão;

- providenciem para que as mesmas sejam rigorosamente cumpridas pelos corpo docente e discente.

\section{BIBLIOGRAFICAS}

9. SEMINARIO SOBRE RESISTENCIA BACTERIANA TRANSFERIVEL. Bevista da Associaçáo Médica Brasileira. Edição Complementar, março, 1973.

10. SOUZA, M.L. Infecçōes em Hospital Pediétrico. Servir. 1(2) :90-95, junho, 1971.

11. TEIXEIRA, E.M. Fontes de infecção no hospital. Revista Paulista de Hospitais. 20(1):7-16, jan. 1972.

12. TIBIRIÇA, C.C. Atuaçāo do pessoal de Enfermagem nas medidas de controle de infecçōes hospitalares. Bevista Brasileira de Enfermagem. 27 (4) :462-471, out./dez. 1974.

13. ULSON, C.M. Apostila sobre infecçāo hospitalar. 27 fls. mimeografadas.

14. ZANON, U. Fundamentos para o controle das infecçōes adquiridas em hospital. O semestre terapêutico. 12 (28):2-12, dez. 1973.

15. ZANON, U., AGUIAR, N., BLEY, J.L., MOH.O, C.G., COSTA C.N., COSTA, B.G. Controle de infecçōes hospitalares. Bevista Paulista de Hospitais. 23(8) :351-360, agosto, 1975.

16. MOURA, M.L.P.A. Aspectos atuais de de enfermagem no controle e tratamento de infecção hospitalar. Revista Brasileira de Enfermagem. 12 (4) :75-84, 1976. 


\section{CRITERIOS PARA IDENTIICÁÇXO DE INFECÇOES HOSPITALARES}

I - INEECÇAO NAO INSTTTUCIONAL, nảo hospitalar ou comunttárle, dellne-se como a infecção constatada no ato da admissąo do paciente, desde que nảo relacionada com internaçāo anterlor no mesmo hospital.

II - INEECCGAO INSTITUCIONAL, hospitalar ou nosocominal, define-so como qualquer infecção que nāo tenha sido diagnosticada no ato da admisså do paciente e que tenha se manifestado duranto a internação ou mesmo depols da alta quando puder ser correlacionada com a hospitalizaçāo.

III - CRITERIOS PARA DIAGNOBTICO DA INEECÇAO INBTITUCIONAL.

1. Normas gerais

1.1. Quando, depols de internado com infecção comunitária, o paciente apresentar sinals e sintomas clínicos de uma infecção em local diferente, ainda quando se tratar do mesmo germe, a caso devera ser classificsdo como infeçãa hospitalar.

1.2. Quando, no mesmo local da infecção diagnosticada no ingresso do paciente no hospital, for Lsolado um germe diferente, o caso deverá ser considerado como infecção hospitalar.

2. Infecção urináris

2.1. Assintomética: confirma-se o diagnóstico com a prosença de 100.000 micro-organismos par millilitio de urina recente, na ausência de qualquer sintoma clínico. Caso o paciente tenha sido admitido com bacteribirla e a cultura posterlor revelar a exdsténcla de um milero-arganlomo diferente em nimero significativo, será considerada infeçāo urinárla institucional.

2.2. Sintomática: confirms-se quando forem registrados pelo menos um dos seguintes elementos: a) 10.000 germes por milliltro de urina recente; b) presença de germes em esfregaço de urins recente nảo centrifugada carada pelo Gram; c) plarla, revelando número supertor a 10 pibcitos por campo.

\section{Infeçōes respiratória}

3.1. Do trato respiratório superior: manifestaçōes clínicas do naria, garganta ou ouvido, isoladas ou comblnadas.

3.2. Do trato resplratório inferlor: slnals o slntomas clinicos, como tosse, dor pleural, febre o outras secreç̋es, sāo consideradas suficlentes para 0 diagn6stlco, mesmo na ausência de ezames radiológlcos ou cultura de escarro. A exdstência de escarro purulento. com ou sem lsolamento de micro-organismo patogênico com 
HORR, L. e Colaboradores - Comissão de controle de infecção hospitalar. Rev. Bras. Enf.; DF, $31:$ 182-192, 1978.

exame radiológico compatível, configura caso de infecção institucional.

4. Gastroenterites institucionais: nos casos em que o periodo de incubação for conhecido (salmonelose, por exemplo) somente serão considerados casos de infecção institucional aqueles em que o tempo de internação for superior ao tempo de incubação da doença.

5. Infecções cutâneas institucionais

5.1. Infecçōes em queimados: o simples isolamento de micro-organismos patogênicos é insuficiente para o diagnóstico, tornando-se indispensável a existência de secreção purulenta na lesão bem como sinais de bacteriemia, para caracterizar a infecção.

5.2. Infecçōes cirúrgicas: qualquer ferida círúrgica que drene material purulento, com ou sem cultura positiva, deve ser considerada como uma infecção institucional, independente de cogitação quanto à origem dos micro-organismos, se endógenos ou exógenos.

5.3. Outras infecçōes cutâneas: dermatites, úlceras de decúbito, quando desenvolvidas depois da admissão do paciente, serão classificadas como infecçōes institucionais. Em pacientes admitidos com infecçōes cutâneas ou subcutâneas, o isolamento de um micro-organismo diferente deverá constituir elemento para classificar o caso como infecção institucional.

6. Outras infecçōes hospitalares

6.1. Bacteriemias: ocorrendo depois da admissão do paciente, documentadas com cultura, devem ser classificadas como infecção hospitalar.

6.2. Infecções por cateter intravenoso ou agulha: drenagem purulenta depois de manipulação e emprego de cateter intravenoso ou punção, deve ser considerada infecção hospitalar, mesmo na ausência de cultura positiva.

6.3. Endometrites: ocorrendo durante a internação, devem ser consideradas institucionais, caracterizando-se por supuração cervical acompanhada de cultura positiva de germe patogênico ou de manifestação sistêmica de infecção.

6.4. Infecçōes intra-abdominais: apendicites, colecistites e divertiticulites não devem ser consideradas infecçōes institucionais. 